Uniwersytet Szczeciński

Katedra Efektywności Innowacji

Natalia Irena Gust-Bardon

\title{
POLITYKA INNOWACYJNA W POLSCE
}

Z a rys treści. Innowacyjność zyskała ogromne znaczenie wśród naukowców, polityków oraz przedsiębiorców od czasu, kiedy została określona jako kluczowy czynnik wzrostu gospodarczego oraz konkurencyjności. Aby procesy innowacyjne mogły być skutecznie kreowane oraz absorbowane, tak aby podnosić konkurencyjność kraju, konieczna jest przemyślana interwencja państwa w postaci polityki innowacyjnej. Jej celem jest stymulowanie współpracy pomiędzy instytucjami naukowymi a przedsiębiorstwami. Współdziałanie pozwoli na wymianę wiedzy oraz doświadczeń, które w końcowym etapie mogą przełożyć się na powstanie nowych rozwiązań technologicznych lub organizacyjnych. W pracy przedstawiono politykę innowacyjną w Polsce, jej główne dokumenty strategiczne oraz podstawę prawną. Wskazano na rosnące znaczenie regionów w kreowaniu polityki innowacyjnej.

Słow a kluczowe: Unia Europejska, polityka innowacyjna, regiony.

\section{WSTĘP}

Poziom innowacyjności gospodarki zależy w dużej mierze od relacji pomiędzy trzema następującymi środowiskami: naukowym, rządowym i przemysłowym. Istota przemysłu $\mathrm{w}$ tych zależnościach polega na zgłaszaniu popytu na nowe metody naukowo-techniczne, a także zapewnianiu podaży innowacji dla konsumentów oraz producentów. Rząd pełni głównie rolę regulacyjną w stosunku do przemysłu i nauki, natomiast środowisko naukowe poprzez wyniki badań oferuje nowe rozwiązania naukowo-techniczne (Jasiński, 2006).

Te działania interwencyjne państwa, które wspierają działalność badawczo-rozwojową i innowacyjną, mają postać polityki innowacyjnej. Zawiera ona również działania publiczne z zakresu szkolnictwa, infrastruktury oraz polityki regionalnej (Edquist, 2001). Poprzez wspieranie innowacyjności państwo 
wspiera tym samym konkurencyjność gospodarki. Klasycznym instrumentem polityki innowacyjnej jest stymulowanie współpracy pomiędzy instytucjami naukowymi a przedsiębiorstwami w celu osiągnięcia innowacyjnych rozwiązań technologicznych lub organizacyjnych (Meyer-Krahmer, 1997). Udział państwa w omawianym procesie jest konieczny ze względu na słabość rynku do samoregulacji, wysokie koszty badań przekraczające zdolność finansową pojedynczych podmiotów gospodarczych oraz potrzebę wspierania strategicznych sektorów gospodarki wysoką technologią (Ciok, 2009).

Edquist (1999) dzieli aktywność interwencyjną państwa w kontekście polityki innowacyjnej na dwie kategorie:

1. Działania stosujące mechanizmy pozarynkowe, polegające na wprowadzaniu regulacji zamiast stosowaniu mechanizmu popytu i podaży (np. darmowa edukacja, finansowanie działalności badawczo-rozwojowej, udogodnienia podatkowe).

2. Działania na rzecz ulepszania funkcjonujących już rynków lub tworzenie nowych (prawo antymonopolowe, prawo patentowe).

Celem pracy jest przedstawienie podstawowych dokumentów kształtujących politykę innowacyjną w Polsce na przestrzeni lat oraz ukazanie regionu jako odpowiedni poziom do prowadzenia polityki innowacyjnej. W artykule omówiono również początkowe fazy tworzenia się polityki innowacyjnej w Unii Europejskiej.

\section{POCZĄTKI POLITYKI INNOWACYJNEJ W UNII EUROPEJSKIEJ}

Polityka innowacyjna zaczęła pojawiać się w dokumentach Unii Europejskiej od lat dziewięćdziesiątych XX wieku. Pierwszy krok w tym kierunku został zapoczątkowany w 1995 r. w „Zielonej Księdze Innowacji” („Green Paper on Innovation”), a następnie w „Pierwszym planie działań na rzecz innowacyjności w Europie” („The First Action Plan for Innovation in Europe”) z 1996 roku. Kamieniem milowym w podejściu do polityki innowacyjnej była Strategia Lizbońska, przyjęta przez Radę Europejską na posiedzeniu w Lizbonie w 2000 roku (Rossi, 2007).

„Zielona Księga Innowacji” stanowiła podstawę do tworzenia europejskiej polityki innowacyjnej w kolejnych latach. Cel dokumentu obejmował identyfikację czynników - zarówno pozytywnych, jak i negatywnych - wpływających na innowacyjność w Europie, a następnie formułowanie działań na rzecz zwiększania zdolności innowacyjnej Unii. Diagnozę wyzwań oraz problemów zawarto w rozdziale II, III i IV (kolejno: „The challenges of innovation”, „The situation 
in Europe”, „Innovation in a straight jacket”), natomiast proponowane sposoby działań określono w rozdziale V „,Routes of actions”. Działania te to m.in.:

- ułatwianie procedur administracyjnych;

- promowanie korzyści płynących z innowacji;

- ulepszanie finansowania innowacji;

- zachęcanie do działań innowacyjnych w przedsiębiorstwach sektora małych i średnich przedsiębiorstw (MŚP);

- modernizowanie działań na rzecz innowacji w sektorze publicznym.

Pierwszy plan działań na rzecz zwiększania zdolności innowacyjnej wskazuje na trzy obszary działań: sprzyjanie kulturze innowacji, ustalanie przewodniej struktury dla innowacji (wprowadzenie regulacji prawnych i finansowych) oraz dostosowywanie badań do innowacji. Dokument podkreśla, że wysiłek w realizacji działań musi być położony zarówno na szczeblu lokalnym, regionalnym oraz krajowym.

Ratyfikowana w marcu 2000 r. Strategia Lizbońska była reakcją przywódców europejskich na powiększającą się lukę w poziomie rozwoju gospodarczego Unii Europejskiej (UE) w stosunku do Stanów Zjednoczonych Ameryki. Strategia stanowiła program działania na rzecz poprawy konkurencyjności gospodarek krajów UE. Za strategiczny cel uznano uczynienie z Unii Europejskiej „najbardziej dynamicznej, konkurencyjnej i opartej na wiedzy gospodarki na świecie, zdolnej do zapewnienia zrównoważonego wzrostu, oferującej więcej lepszych miejsc pracy oraz większą spójność społeczną, jak również dbającej o poszanowanie środowiska naturalnego". Czas na realizację tego zamierzenia został wyznaczony do 2010 r. Innowacyjność uznano za podstawę konkurencyjności gospodarki.

Strategia zakończyła się niepowodzeniem, wyprzedzenie Stanów Zjednoczonych Ameryki pod względem technologicznym okazało się niemożliwe w tak krótkim czasie. Za największą porażkę uznaje się wydatki na naukę w Unii Europejskiej, które stanowią około 2,01 procent $\mathrm{PKB}^{1}$ - natomiast strategia zmierzała do osiągnięcia 3 procent PKB do roku 2010. Przez 10 lat finansowanie badań naukowych w krajach UE nie uległo zwiększeniu. Przewiduje się, że to Chiny do 2020 roku mogą stać się liderem w światowej nauce oraz w dziedzinie nowoczesnych technologii (Kościelniak, 2010).

Przyczyn niepowodzeń upatruje się między innymi w słabym przywództwie politycznym w UE. Niektórzy jednak dostrzegają pozytywne aspekty, zaznaczając, że sama próba osiągnięcia postawionych celów - które na pewno były planami bardzo ambitnymi - wskazała Europejczykom nowy sposób myślenia o czynnikach rozwoju. 
W styczniu 2010 roku Europejski Komitet Ekonomiczno-Społeczny opracował zintegrowany raport pt. „Strategia (lizbońska) po roku 2010: Propozycje zorganizowanego społeczeństwa obywatelskiego". Komitet opowiada się za kontynuacją kompleksowej strategii po 2010 r. Podkreśla jednak, że czynności muszą zostać zmienione i stać się adekwatną odpowiedzią na wyzwania dzisiejszych czasów. Obecne działania powinny być zgodne z zasadą zrównoważonego rozwoju, „która będzie łączyć badania i rozwój, innowacje oraz konkurencyjność z innowacyjnym potencjałem społecznej Europy" (Zintegrowany raport, 2010, s. 14). Proponowane kierunki działań to między innymi:

- inwestycje w innowacje w dziedzinie usług publicznych, które mają przyczynić się do odbudowania zaufania ludzi do Unii Europejskiej;

- dążenie do oszczędzania zasobów oraz produkcji i konsumpcji wiążącej się z niską emisją;

- efektywna regulacja rynków finansowych.

Działania przewidziane w strategii po roku 2010 koniecznie powinny zwiększać znaczenie trójkąta wiedzy (badania, innowacje, kształcenie) - podkreślają autorzy raportu. Europa musi kontynuować wzmacnianie potencjału innowacyjnego, tworzącego siłę napędową konkurencyjności, poprzez podnoszenie kwalifikacji obywateli UE oraz zwiększanie potencjału leżącego w nauce, badaniach i technologii. Komitet zaznacza konieczność poszerzenia pojęcia innowacji o innowacje społeczne w celu intensyfikowania kapitału społecznego - niezbędnego dla spójności społecznej i dla konkurencyjności. Dla zapewnienia gruntu dla przyszłych innowacji autorzy postulują za nadaniem wyższej rangi nauce i badaniom oraz skupić uwagę na wykorzystywaniu ich rezultatów w praktyce gospodarczej. Zwracają także uwagę na odpowiedzialność uniwersytetów i instytucji kształcenia $\mathrm{w}$ procesie podnoszenia innowacyjności oraz na słabość przedsiębiorstw w inwestowaniu w badania i rozwój. Zmiany powinny przebiegać w kierunku większego inwestowania przedsiębiorstw w te obszary i tworzenia produktywnych miejsc pracy (Zintegrowany raport, 2010, s. 20).

\section{POLSKIE PODEJŚCIE DO POLITYKI INNOWACYJNEJ}

Analizę polityki innowacyjnej w przekroju czasowym można podzielić na trzy badane okresy: okres przed transformacją, okres transformacji systemowej, okres członkostwa Polski w Unii Europejskiej.

Do roku 1989 polityka innowacyjna praktycznie nie istniała. Do czasu transformacji gospodarkę polską charakteryzował ekstensywny rozwój gospodarczy rozwój poprzez uruchomienie dodatkowych czynników produkcji przy niezmiennym poziomie wydajności pracy (wzrost zatrudnienia, wzrost inwestycji, wzrost 
surowców itp.). Tradycyjne czynniki wzrostu nie zrodziły chęci ani potrzeby do poszukiwania efektywniejszych, konkurencyjnych rozwiązań technologicznych. Naukę sprowadzano jedynie do roli kulturotwórczej, dlatego polityka naukowa i polityka przemysłowa istniały jako dwa oddzielne działania polityczne (Ciok, 2009).

Proces transformacji systemowej i przemiana gospodarki na gospodarkę rynkową sprawiły, że kraj otworzył się na rynki zewnętrzne, co wywołało wzrost konkurencyjności. Sprostać tej konkurencyjności mogła jedynie gospodarka innowacyjna. Otwarcie kraju, ożywione przekształcenia wewnętrzne oraz czynniki zewnętrzne spowodowały zapotrzebowanie na odpowiednią politykę innowacyjną. Dopiero od tego okresu, czyli od lat 90 . XX wieku, można mówić o polityce innowacyjnej, która stanowiła już samodzielną dziedzinę. Zaczęły pojawiać się dokumenty strategiczne, nowe akty prawne, programy wspierające innowacyjność. Stosowano wówczas w głównej mierze narzędzia finansowe. Ważniejsze dokumenty rządowe, oddziałujące na innowacyjność gospodarki polskiej w tym okresie, to m.in. (Dobrowolska-Kaniewska, 2008):

- „Założenia polityki naukowej i naukowo-technicznej państwa” (dokument przyjęty przez Radę Ministrów 20 lipca 1993 r.);

- „Założenia polityki proinnowacyjnej państwa” (przyjęty 22 listopada 1994 r.);

- „Międzynarodowa konkurencyjność polskiego przemysłu” (przyjęty 16 maja 1995 r.);

- „Podstawy dla polityki naukowej i technologicznej” (przyjęty 16 stycznia 1996 r.);

- „Program wspierania rozwoju instytucji regionalnych działających na rzecz transferu technologii w sektorze MŚP” (przyjęty 4 marca 1997 r.);

- „Założenia polityki innowacyjnej państwa do 2002 roku” (przyjęty 6 grudnia 1999 r.);

- „Zwiększanie innowacyjności gospodarki w Polsce do 2006 roku” (przyjęty 11 lipca 2000 r.);

Próby oceny polityki innowacyjnej w okresie transformacji podjął się Jasiński (2004). Po analizie dokumentów przyjętych przez Radę Ministrów do roku 2000 stwierdził, że:

- instrumenty polityki innowacyjnej opierały się głównie na narzędziach finansowych;

- narzędzia polityki nie były adresowane do branż wysokiej technologii;

- dominowały instrumenty strony podażowej;

- instrumenty polityki kierowane były w stronę generowania innowacji, mniej natomiast w kierunku ich dyfuzji; 
- polityka innowacji była silnie scentralizowana, głównie w sferze finansowania badań naukowych;

- miał miejsce brak długookresowej strategii rozwoju nauki i techniki.

Analizę okresu członkostwa Polski w Unii Europejskiej można zacząć od ważnego kroku, jakim było przyjęcie ustawy o niektórych formach wspierania działalności innowacyjnej (Dz. U. z 2005 r. Nr. 179, poz. 1484). Głównym celem ustawy jest wzrost innowacyjności i konkurencyjności gospodarki. Został on podzielony na węższe cele: rozwój prywatnego sektora działalności badawczo-rozwojowej i wzrost nakładów przedsiębiorstw na badania i rozwój, zwiększenie efektywności wdrażania polityki innowacyjnej w skali kraju oraz na poziomie regionalnym, optymalizację efektów z wykorzystanych środków publicznych na działalność innowacyjną. W realizacji powyższych zamierzeń miał posłużyć kredyt technologiczny oraz nadanie przedsiębiorcy statusu centrum badawczo-rozwojowego. Ponadto, rozszerzono zakres zadań Polskiej Agencji Rozwoju Przedsiębiorczości, aby zwiększyć skuteczność wdrażania polityki. Kolejnym ważnym dokumentem z tego okresu są „Kierunki zwiększania innowacyjności gospodarki na lata 2007-2013", przyjęte 4 grudnia 2006 roku, będące kontynuacją programu rządowego „Zwiększanie innowacyjności gospodarki w Polsce do 2006 roku”. Strategicznym celem tego opracowania jest „wzrost innowacyjności przedsiębiorstw dla utrzymania gospodarki na ścieżce szybkiego rozwoju i dla tworzenia nowych, lepszych miejsc pracy" (Kierunki, 2006, s. 58). Opis pozostałych wybranych dokumentów wpływających na poziom innowacyjności gospodarki został przedstawiony w tabeli 1 .

Po analizie przedstawionych dokumentów można stwierdzić, że obecnie politykę innowacyjną cechuje ( $\mathrm{w}$ porównaniu $\mathrm{z}$ okresem transformacji systemowej):

- zróżnicowanie instrumentów, np.: kształcenie na różnych poziomach, usługi doradcze dla sektora MŚP, instrumenty prawne i regulacyjne, rozwój nauki przez granty, rozbudowa infrastruktury wspierającej innowacyjną działalność (np. parki technologiczne);

- podkreślanie znaczenia polityki innowacyjnej ukierunkowanej na popyt (np. wskazywanie na znaczenie zamówień publicznych w procesie innowacji);

- tworzenie długookresowych programów, strategii;

- dostrzeżenie znaczenia podejścia regionalnego w polityce innowacyjnej.

Cechy te wskazują na wiele pozytywnych zmian, jakie zaszły od czasów rozpoczęcia transformacji systemowej w sferze polityki innowacyjnej. Należy jednak zwrócić uwagę, że formułowane cele w programach i strategiach muszą być możliwe do zrealizowania. Niestety, zdarza się, że pojawiają się cele zupełnie nieosiągalne $\mathrm{w}$ zakładanym okresie czasowym, jak miało to miejsce na 
Tabela 1. Wybrane dokumenty dotyczące polityki innowacyjnej od $2000 \mathrm{r}$.

\begin{tabular}{|c|c|}
\hline Dokument lub program & Uwagi \\
\hline $\begin{array}{l}\text { Zwiększanie } \\
\text { innowacyjności gospodarki } \\
\text { w Polsce do } 2006 \text { roku }\end{array}$ & $\begin{array}{l}\text { Program przyjęty przez Radę Ministrów } 11 \text { lipca } 2000 \text { roku. Wskazano w nim cztery głów- } \\
\text { ne priorytety do realizacji: tworzenie mechanizmów i struktur sprzyjających działalności } \\
\text { innowacyjnej, kształtowanie postaw innowacyjnych, zwiększenie sprawności wdrażania } \\
\text { nowoczesnych rozwiązań w gospodarce, zmiana wzorców konsumpcji i modeli produkcji } \\
\text { w Polsce na korzystniejsze dla trwałego, zrównoważonego rozwoju. Każdy priorytet okre- } \\
\text { ślony został przez działania. Z } 21 \text { działań aż } 19 \text { zostało zrealizowanych. }\end{array}$ \\
\hline $\begin{array}{l}\text { Koncepcja Polityki } \\
\text { Przestrzennego } \\
\text { Zagospodarowania Kraju }\end{array}$ & $\begin{array}{l}\text { Program opracowany przez Rządowe Centrum Studiów Strategicznych (organ już nie- } \\
\text { istniejący), drukiem ukazał się w } 2001 \text { roku (M. P. z } 2001 \text { r. Nr } 26 \text { poz. 432). Dokument } \\
\text { podkreśla konieczność dążenia do dynamizacji polskiej przestrzeni w europejskim syste- } \\
\text { mie innowacyjności i konkurencyjności poprzez tworzenie lokalnych, regionalnych oraz } \\
\text { europejskich systemów innowacji. }\end{array}$ \\
\hline $\begin{array}{l}\text { Narodowy Plan Rozwoju } \\
\text { na lata } 20042006\end{array}$ & $\begin{array}{l}\text { Dokument przyjęty przez Radę Ministrów } 14 \text { stycznia } 2003 \text { roku. Wdrażany za pomocą } \\
\text { programów operacyjnych i projektów Funduszu Spójności. Jest strategicznym dokumen- } \\
\text { tem planistycznym, scalającym sektorowe, horyzontalne i regionalne działania państwa. } \\
\text { Celem strategicznym jest rozwijanie konkurencyjnej gospodarki opartej na wiedzy i przed- } \\
\text { siębiorczości, zdolnej do długofalowego, harmonijnego rozwoju, zapewniającej wzrost } \\
\text { zatrudnienia oraz poprawę spójności społecznej, ekonomicznej i przestrzennej z Unią } \\
\text { Europejską na poziomie regionalnym i krajowym. Cel strategiczny został rozbity na pięć } \\
\text { celów cząstkowych. }\end{array}$ \\
\hline $\begin{array}{l}\text { Ustawa z dnia } 8 \\
\text { października } 2004 \text { r. } \\
\text { o zasadach finansowania } \\
\text { nauki (Dz. U. z 2004 r. } \\
\text { Nr 238, poz. 2390) }\end{array}$ & $\begin{array}{l}\text { Ustawa wprowadza rozwiązania organizacyjno-prawne mające na celu zintensyfikowanie } \\
\text { realizacji badań stosowanych oraz prac rozwojowych, a także rozwijanie aktywnej polityki } \\
\text { innowacyjnej państwa. Ustawa powołuje Radę Nauki - ciało doradcze ministra właściwe- } \\
\text { go ds. nauki. Wzmocniona została pozycja ministra, który odpowiada za politykę nauko- } \\
\text { wą, naukowo-techniczną, decyduje o podziale środków finansowych na naukę. Ustawa } \\
\text { kładzie nacisk na budowanie sieci naukowych. }\end{array}$ \\
\hline $\begin{array}{l}\text { Założenia polityki } \\
\text { naukowej, } \\
\text { naukowo-technicznej } \\
\text { i innowacyjnej państwa } \\
\text { do } 2020 \text { roku }\end{array}$ & $\begin{array}{l}\text { Dokument przyjęty przez Radę Ministrów } 14 \text { grudnia } 2004 \text { roku. Ma on charakter ramowy, } \\
\text { wyznacza ogólne cele i priorytety do } 2020 \text { roku. Podkreśla się w nim znaczenie powią- } \\
\text { zania nauki z innowacyjnym biznesem oraz potrzebę zwiększania udziału finansowania } \\
\text { nauki ze źródeł pozabudżetowych. Dokument wskazuje na rolę regionalnych strategii in- } \\
\text { nowacji w procesie innowacyjności i konkurencyjności regionów. }\end{array}$ \\
\hline $\begin{array}{l}\text { Ustawa z dnia } 4 \text { marca } \\
2005 \text { r. o Krajowym Fundu- } \\
\text { szu Kapitałowym (Dz. U. } \\
\text { z } 2005 \text { r. Nr } 57 \text {, poz. 491) }\end{array}$ & $\begin{array}{l}\text { Krajowy Fundusz Kapitałowy ma na celu gromadzenie, a następnie udostępnianie środ- } \\
\text { ków finansowych funduszom kapitałowym, które zobligują się do zainwestowania w sek- } \\
\text { tor MŚP. Opisywany fundusz będzie zachęcał inwestorów do inwestowania w działania } \\
\text { przedsiębiorstw innowacyjnych. }\end{array}$ \\
\hline $\begin{array}{l}\text { Krajowy Program Reform } \\
\text { na lata } 20052008 \text { na } \\
\text { rzecz realizacji Strategii } \\
\text { Lizbońskiej }\end{array}$ & $\begin{array}{l}\text { Przyjęty przez Radę Ministrów } 27 \text { grudnia } 2005 \text { roku. Głównym celem dokumentu jest } \\
\text { utrzymanie wysokiego tempa wzrostu gospodarczego, sprzyjającego tworzeniu nowych } \\
\text { miejsc pracy, z zachowaniem zasad zrównoważonego rozwoju. Program został podzie- } \\
\text { lony na trzy bloki: obszar polityki makroekonomicznej i budżetowej, obszar polityki mi- } \\
\text { kroekonomicznej i strukturalnej oraz obszar polityki rynku pracy. Dla każdego z obszarów } \\
\text { wyróżniono priorytety. W obszarze mikroekonomicznym wyznaczono ich cztery: rozwój } \\
\text { przedsiębiorczości, wzrost innowacyjności przedsiębiorstw, rozwój i modernizacja infra- } \\
\text { struktury oraz zapewnienie warunków konkurencji w sektorach sieciowych. }\end{array}$ \\
\hline
\end{tabular}




\begin{tabular}{|c|c|}
\hline $\begin{array}{l}\text { Strategia Rozwoju Kraju } \\
20072015\end{array}$ & $\begin{array}{l}\text { Strategia została przyjęta przez Radę Ministrów } 29 \text { listopada } 2006 \text { roku. Jest dokumen- } \\
\text { tem nadrzędnym, stanowi punkt odniesienia dla innych programów rządowych. Głównym } \\
\text { celem strategii jest podniesienie poziomu i jakości życia mieszkańców Polski. Cel ten } \\
\text { przekłada się na sześć priorytetów. Pierwszy priorytet wskazuje na wzrost konkurencyj- } \\
\text { ności i innowacyjności gospodarki, który ma być on osiągany poprzez: rozwój przedsię- } \\
\text { biorczości, wzrost nakładów na działalność badawczo-rozwojową i innowacje oraz rozwój } \\
\text { społeczeństwa informatycznego. }\end{array}$ \\
\hline $\begin{array}{l}\text { Program Operacyjny } \\
\text { Innowacyjna Gospodarka } \\
\text { na lata } 20072013\end{array}$ & $\begin{array}{l}\text { Program przyjęty przez Radę Ministrów } 30 \text { października } 2007 \text { roku. Stanowi on jeden } \\
\text { z } 6 \text { programów Narodowych Strategicznych Ram Odniesienia. Finansowany jest ze środ- } \\
\text { ków europejskich. Program wspiera działania z zakresu innowacyjności procesowej, pro- } \\
\text { duktowej, organizacyjnej oraz marketingowej. Istotną informacją jest to, że wsparcie nie } \\
\text { będzie udzielane na poziomie lokalnym i regionalnym. Oznacza to, że program wspiera } \\
\text { projekty innowacyjne, ale co najmniej w skali kraju lub na poziomie międzynarodowym. } \\
\text { Celem dokumentu jest rozwój gospodarki poprzez innowacyjne przedsiębiorstwa; jego } \\
\text { osiągnięcie ma nastąpić poprzez realizację ośmiu osi priorytetowych. }\end{array}$ \\
\hline $\begin{array}{l}\text { Nowe podejście do } \\
\text { zamówień publicznych }\end{array}$ & $\begin{array}{l}\text { Dokument przyjęty przez Radę Ministrów } 8 \text { kwietnia } 2008 \text { roku. Opracowanie wskazuje } \\
\text { na konieczność zmian m.in. w takich sferach jak zwiększenie udziału MŚP w systemie } \\
\text { zamówień publicznych czy zwiększanie popytu na innowacyjne usługi i produkty poprzez } \\
\text { system zamówień publicznych. W dokumencie podkreślono, że innowacyjne zamówienia } \\
\text { publiczne powinny być elementem polityki innowacyjnej. Sektor publiczny rozumiany jest } \\
\text { tutaj jako „inteligentny klient”. Administracja publiczna powinna dawać przykład poprzez } \\
\text { wspieranie realizacji najefektywniejszych projektów. }\end{array}$ \\
\hline $\begin{array}{l}\text { Krajowy Program Reform } \\
\text { na lata } 20082011 \text { na } \\
\text { rzecz realizacji Strategii } \\
\text { Lizbońskiej }\end{array}$ & $\begin{array}{l}\text { Dokument przyjęty przez Radę Ministrów } 18 \text { listopada } 2008 \text { roku. Głównym celem pro- } \\
\text { gramu jest stworzenie w Polsce najlepszych w Europie warunków do prowadzenia dzia- } \\
\text { łalności gospodarczej. Wskazano na trzy obszary priorytetowe: aktywne społeczeństwo, } \\
\text { innowacyjna gospodarka, sprawne instytucje. }\end{array}$ \\
\hline
\end{tabular}

Źródło: Opracowanie własne

przykład w „Krajowym Programie Reform na lata 2008-2011 na rzecz realizacji Strategii Lizbońskiej”, gdzie za główny cel obrano „stworzenie w Polsce najlepszych w Europie warunków do prowadzenia działalności gospodarczej”. Unia Europejska, ogłaszając Strategię Lizbońską, także określała bardzo ambitne cele; plan zakładał, że Wspólnota do roku 2010 stanie się „najbardziej dynamiczną, konkurencyjną i opartą na wiedzy gospodarki na świecie”. Zamierzenia tego nie udało się jednak osiągnąć.

Bardzo ważną zmianą jest dostrzeżenie znaczenia regionalnego podejścia do procesów innowacyjnych. Regionalny charakter oznacza tutaj głównie aktywną, przychylną innowacjom politykę władz oraz samorządów na szczeblu lokalnym i wojewódzkim. Nowe stanowisko do strategii rozwoju gospodarczego - aby zerwać z dominacją pojedynczych inwestorów, którzy stanowili o sile regionu ukierunkowane jest na poszukiwanie trwałych fundamentów rozwoju wewnątrz regionów (Klepka, 2006). Takie podejście rodzi potrzebę zaangażowania do 
współpracy środowisk lokalnych: administracji, nauki, biznesu, instytucji naukowo-badawczych, instytucji pozarządowych. W ten sposób tworzą się układy sieciowe, składające się na regionalny system innowacji.

\section{POLITYKA INNOWACJI - POZIOM REGIONALNY}

Od lat dziewięćdziesiątych XX wieku obserwowana jest utrata na znaczeniu poziomu narodowego na rzecz regionów, które stają się głównym celem działań gospodarczych. Naukowcy wskazują na wiele czynników, które spowodowały to przesunięcie. Ohmae (1995) upatruje przyczynę w tym, że regiony są bardziej dynamiczne i elastyczne w działalności badawczo-rozwojowej i gospodarczej. Inni uważają, że po prostu łatwiej jest prowadzić politykę gospodarczą w skali regionalnej niż globalnej (Doloreux i Parto, 2005). Niektórzy eksperci wysuwają pogląd, że XXI wiek będzie wiekiem regionalizacji (Chung, 2002).

Kreowanie polityki innowacyjnej z poziomu regionalnego jest zasadne z kilku powodów. Po pierwsze, regiony różnią się między sobą poziomem rozwoju gospodarczego, specjalizacją w zakresie przemysłu, potencjałem innowacyjnym - to wszystko rodzi konieczność stosowania zróżnicowanych polityk innowacyjnych skierowanych do poszczególnych województw. Po drugie, procesy innowacyjne charakteryzuje regionalność - transfer wiedzy, szczególnie nieskodyfikowanej (tacit knowledge), wymaga bezpośrednich kontaktów zachodzących w określonej bliskości geograficznej (Tödtling i Trippl, 2005).

Efekty polityki innowacyjnej prowadzonej na poziomie regionu powinny prowadzić do utworzenia oraz rozwoju regionalnych systemów innowacji (RSI), przez które rozumie się zbiór podmiotów i instytucji w regionie, które są bezpośrednio związane z generowaniem, dyfuzją i adaptacją innowacji technologicznych, oraz relacje zachodzące pomiędzy tymi podmiotami. RSI tworzą trzy główne grupy innowacyjnych aktorów: uniwersytety, przedsiębiorstwa, instytucje publiczne (Chung, 2002).

W Polsce ważnym krokiem w kierunku tworzenia regionalnych systemów innowacji było zapoczątkowanie procesu budowania regionalnych strategii innowacji w latach 2000-2005. Opracowano wówczas strategie w 15 województwach, a następnie dokumenty te zostały przyjęte przez Sejmiki Samorządowe w okresie 2003-2005 roku. W roku 2006 województwo mazowieckie podjęło prace nad zdefiniowaniem strategii. Polska jest jednym z nielicznych krajów UE, w którym regionalne strategie innowacji zostały opracowane we wszystkich regionach. 


\section{PODSUMOWANIE}

Rosnące znaczenie regionów w procesie innowacji (Asheim i Isaksen, 1997; Isaksen, 2001) spowodowało, że naukowcy oraz politycy zaczęli mówić o regionalnej polityce innowacji (Koschatzky, 2009). Jednakże, konieczność współpracy pomiędzy regionami, sektorami, a nawet państwami w celu wymiany doświadczeń oraz wiedzy nie doprowadziła do dewaluacji znaczenia poziomu krajowego w kształtowaniu polityki innowacyjnej. Region nie może stać się odosobnioną wyspą, działającą bez współpracy i kontaktu z pozostałymi regionami (Koschatzky, 2009). Tworzenie warunków do współpracy pomiędzy regionami w skali kraju oraz w skali globalnej powinno stać się instrumentem polityki innowacyjnej koordynowanej z poziomu krajowego.

Podstawowy instrument regionalnej polityki innowacyjnej w Polsce stanowią regionalne strategie innowacji. Ich realizacja wspierana jest przez urzędy marszałkowskie. Jednym z głównych celów strategii innowacji jest stworzenie regionalnego systemu innowacji, dzięki któremu możliwe jest podniesienie poziomu konkurencyjności regionu.

Celem polityki innowacyjnej, poza stymulowaniem współpracy pomiędzy instytucjami naukowymi a przedsiębiorstwami, jest tworzenie otoczenia regulującego. Ponadto, według zaleceń Unii Europejskiej (COM/2006/502/FINAL), sektor publiczny powinien dawać przykład społeczeństwu poprzez wprowadzanie innowacyjnych metod działań oraz wykorzystywać nowe technologie i procedury w administracji publicznej.

\section{LITERATURA}

Asheim B., Isaksen A., Location, agglomeration and innovation: towards regional innovation systems in Norway? European Planning Studies, 1997, tom 5, nr 3, s. 299-330.

Chung S., Building a national innovation system through regional innovation systems. Technovation, 2002, tom 22, nr 8, s. 485-491.

Ciok S., Polityka rząu wobec wspierania działalności innowacyjnej i badawczo-rozwojowej. [w:] Dobrowolska-Kaniewska H., Korejwo E. (red.), Endo i egzogeniczne determinanty obszarów wzrostu i stagnacji w województwie dolnoślaskim w kontekście Dolnośląskiej Strategii Innowacji. Wrocław: Dolnośląska Agencja Współpracy Gospodarczej, 2009, s. 119-145.

Dobrowolska-Kaniewska H., Potencjat innowacyjny i jego wykorzystanie w wybranych sektorach gospodarki Dolnego Ślaska. Wrocław: Uniwersytet Wrocławski, Instytut Geografii i Rozwoju Regionalnego, Zakład Zagospodarowania Przestrzennego, 2008. Rozprawa doktorska. 
Doloreux D., Parto S., Regional innovation system: Current discourse and unresolved issues. Technology in Society, 2005, tom 27, nr 2, s. 133-153.

Edquist C., The Systems of Innovation Approach and Innovation Policy: An account of the state of the art. Lead paper presented at the DRUID Conference, Aalborg, 2001.

Edquist C., Innovation policy - a systemic approach. [w:] Archibugi D., Lundvall B. A. (red.), The Globalizing Learning Economy, Oxford, 2002, s. 219-238.

Isaksen A., Building regional innovation systems: Is endogenous industrial development possible in the global economy? Canadian Journal of Regional Science, 2001, tom 24, nr 1, s. 101-124.

Jasiński A. H., Jaka polityka innowacyjna w okresie transformacji? Sprawy nauki, 2004, tom 97,nr 2. Biuletyn Ministerstwa Nauki i Szkolnictwa Wyższego.

Jasiński A. H., Innowacje i transfer techniki w procesie transformacji. Warszawa: Difin, 2006.

Koschatzky K., The uncertainty in regional innovation policy: some rationales and tools for learning in policy making. Working Papers Firms and Region, No. R6/2009, Fraunhhofer ISI, Karlsruhe.

Kościelniak P., Pogłoski o śmierci nauki w USA sa przesadzone. Rzeczpospolita, 2010, tom 8533, nr 22.

Kwiatkowski S., Społeczeństwo innowacyjne. Warszawa: PWN, 1990.

Meyer-Krahmer F., Technologiepolitik. [w:] Ropohl D., Schmid A. (red.), Handbuch zur Arbeitslehre. München: Oldenbourg, 1997, 731-752.

Ohmae K., The End of the Nation State: The Rise of Regional Economies. 1st Edition. New York: The Free Press, 1995.

Rossi F., Innovation policy in the European Union: instruments and objectives. Munich: Munich University Library, 2007. MPRA [Munich Personal RePEc - Research Papers in Economics - Archive] Paper.

Tödtling F., Trippl M., One size fits all? Towards a differentiated regional innovation policy approach. Research Policy, 2005, tom 34, nr 8, s. 1203-1219.

Zintegrowany raport. Strategia (lizbońska) po roku 2010: Propozycje zorganizowanego społeczeństwa obywatelskiego. Europejski Komitet Ekonomiczno-Społeczny, 2010. Zintegrowany raport dla Rady Europejskiej.

\section{USTAWY ORAZ DOKUMENTY RZĄDOWE:}

Kierunki. Kierunki zwiększania innowacyjności gospodarki na lata 2007-2013. Ministerstwo Gospodarki. Departament Rozwoju Gospodarki, Warszawa, 2006.

Koncepcja Polityki Przestrzennego Zagospodarowania Kraju, Monitor Polski z 2001 r., Nr 26, poz. 432.

Krajowy Program Reform na lata 2005-2008 na rzecz realizacji Strategii Lizbońskiej. Warszawa, 28 grudnia $2005 \mathrm{r}$.

Krajowy Program Reform na lata 2008-2011 na rzecz realizacji Strategii Lizbońskiej, Ministerstwo Gospodarki.

Narodowy Plan Rozwoju na lata 2004-2006, Warszawa, styczeń 2003 r. 
Nowe podejście do zamówień publicznych: Zamówienia publiczne a małe i średnie przedsiębiorstwa, innowacje i zrównoważony rozwój, Ministerstwo Gospodarki, Warszawa, 19 marca $2008 \mathrm{r}$.

Program Operacyjny Innowacyjna Gospodarka na lata 2007-2013, Ministerstwo Rozwoju Regionalnego, Narodowe Strategiczne Ramy Odniesienia 2007-2013, Warszawa, 1 października $2007 \mathrm{r}$.

Strategia Rozwoju Kraju 2007-2015, Ministerstwo Rozwoju Regionalnego, Warszawa, listopad $2006 \mathrm{r}$.

Założenia polityki naukowej, naukowo-technicznej i innowacyjnej państwa do 2020 roku, ministerstwo Nauki i Informatyzacji, Warszawa, grudzień 2004 r.

Zwiększanie innowacyjności gospodarki w Polsce do 2006 roku, Ministerstwo Gospodarki Departament Strategii Gospodarcze, Warszawa, lipiec 2000.

Ustawa z dnia 8 października 2004 r. o zasadach finansowania nauki (Dz. U. z 2004 r. $\mathrm{Nr} 238$, poz. 2390).

Ustawa z dnia 4 marca 2005 r. o Krajowym Funduszu Kapitałowym (Dz. U. z 2005 r. Nr 57, poz. 491).

\section{INNOVATION POLICY IN POLAND}

Abstract. The innovation has gained tremendous importance amongst scientists, politicians, and entrepreneurs since it was identified as the key factor of the economic growth and competitiveness. In order for innovation processes to be efficiently created and absorbed, so that the competitiveness of the country is increased, a thoughtful intervention of the state in terms of an innovation policy is necessary. Its goal is to stimulate the cooperation between the scientific institutions and enterprises. The cooperation is going to allow the exchange of knowledge and experiences, which can result in creating new technological and organisational solutions in its final stage. This work features the innovation policy in Poland, its main strategical documents, and the legal basis. The increasing significance of the regions in creating the innovation policy has been pointed out.

Ke y word s : European Union, innovation policy, regions. 